\title{
ERIOCAULON MEENACHILENSE, A NEW TUBEROUS SPECIES OF ERIOCAULACEAE FROM THE SOUTHERN WESTERN GHATS, INDIA
}

\author{
P. B. Anoop ${ }^{1,2 \star} \&$ A. J. Robi ${ }^{1}$
}

\begin{abstract}
Eriocaulon meenachilense, a new species of the family Eriocaulaceae from the southern Western Ghats, India, is described and illustrated. The new species is similar to Eriocaulon idukkianum and $E$. tuberiferum but differs in its short, linear-subulate, stiff leaves, solitary 6-angled peduncle, inflexed involucral bracts, eglandular petals, and yellow anthers and seeds.
\end{abstract}

Keywords. Eriocaulon, India, Kerala, new species, pipewort, root tuber, Western Ghats. Received 19 February 2020 Accepted 17 August 2020 Published 09 March 2021

\section{Introduction}

Eriocaulaceae, the pipewort family, is distributed mainly in tropical and warm temperate regions and comprises approximately 1400 species across about 10 genera (Giulietti et al., 2012). Members of this family are often difficult to identify in the field because there are few diagnostic vegetative characters and the floral parts are minute. Eriocaulon L. is represented by approximately 400 species worldwide, with centres of diversity in South America, Africa and the Indian subcontinent (Leach, 2017).

Eriocaulon is the sole representative of the family in India. Ansari \& Balakrishnan (2009) recognised 80 species from the country, of which 54 are endemic, with the greatest concentration in Peninsular India. Ansari \& Balakrishnan's list omitted species described earlier by Bole \& Almeida (1986) and Yadav et al. (2008) and species recorded by Myrthong et al. (1983). Several new species have been described from India since publication of the list (Shimpale et al., 2009; Shimpale \& Yadav, 2010; Vivek et al., 2010; Nampy et al., 2011; Biju et al., 2012; Swapna et al., 2012; Sunil et al., 2013; Rashmi \& Krishnakumar, 2014; Sunil et al., 2014; Manudev et al., 2015; Sunil \& Naveen Kumar, 2015; Anto \& Reshma, 2017; Biju et al., 2017; Darshetkar et al., 2017; Manudev et al., 2017; Naveen Kumar et al., 2017; Paithane et al., 2017; Sunil et al., 2017; Chandore et al., 2019; Darshetkar et al., 2019; Khanna \& Kumar, 2019; Francis et al., 2020), and in India the genus is currently represented by 109 species, including the species newly described here.

During the course of a recent botanical exploration of the Illikkal Hills in the southern Western Ghats of India, an interesting specimen of Eriocaulon with root tubers was collected. In Indian Eriocaulon, the presence of a subterranean tuber was previously known only in E. idukkianum Manudev, Robi \& Nampy and E. tuberiferum A.R.Kulk. \& Desai, both of

\footnotetext{
${ }^{1}$ Department of Botany, Bishop Abraham Memorial College, Thuruthicad, Pathanamthitta, Kerala, India. ${ }^{2}$ KSCSTE-Malabar Botanical Garden and Institute for Plant Sciences, P.B. No. 1, Kozhikode, Kerala, India. * Corresponding author. E-mail: anooppb01@gmail.com.
} 
which are endemic to the Western Ghats of India. On critical examination of the specimens and comparison with the protologues of related species, the plant is found to be distinct from both the tuberous taxa and other members of the genus, and it is described and illustrated here as a new species.

\section{Species description}

\section{Eriocaulon meenachilense Anoop \& Robi, sp. nov.}

Eriocaulon meenachilense resembles E. tuberiferum A.R.Kulk. \& Desai in its root tubers, short, linear leaves and free female sepals. However, the new taxon differs in its solitary, 6-angled peduncle, short sheath, white inflorescences, inflexed involucral bracts, free male sepals, eglandular petals, yellow anthers and unappendaged yellow seeds. It also similar to Eriocaulon idukkianum Manudev, Robi \& Nampy, another tuberous species from the Western Ghats that has linear leaves, white inflorescences, male flowers with free sepals and unappendaged seeds, but differs from that species in the absence of a root stock, its hairy, not glabrous root tubers, its solitary, 6-angled peduncle, and its glabrous receptacle, eglandular petals and yellow anthers and seeds. - Type: India, Kerala, Kottayam District, Meenachil, Illikkal Hills, c. 1000 m a.s.l., 7 x 2019, Anoop. P. B. \& A. J. Robi 15934 (holotype MH!, isotype BAM!, MBGH!). Figures 1, 2.

Acaulescent herb. Rootstock absent; root tubers 2 or 3, subglobose, 5-6 $\times$ 4-5 mm, villous, cream-coloured. Leaves rosulate, linear-subulate, stiff, $2.5-3.5 \times 0.1-0.2 \mathrm{~cm}$, glabrous, 3 - or 4-nerved, nervules inconspicuous. Peduncle solitary, $12-20 \mathrm{~cm}$ high, $0.4-0.5 \mathrm{~mm}$ across, 6-angled, twisted, glabrous; sheaths $2-3 \mathrm{~cm}$ long, glabrous, striate; limb 1.5-2.5 mm long, incised. Inflorescence hemispherical, 5-6 $\times$ 4-5 mm, white. Receptacle convex, glabrous. Involucral bracts inflexed, obovate, acute at apex, 1.2-1.5 $\times 0.8-1 \mathrm{~mm}$, black-hyaline, entire, chartaceous, glabrous. Floral bracts oblanceolate, acuminate, $1.2-1.5 \times 0.6-0.8 \mathrm{~mm}$, black, hoary towards apex. Staminate flowers: pedicels $0.1-0.2 \mathrm{~mm}$ long, glabrous; sepals 3 , free, broadly oblanceolate, 1-1.2 × 0.3-0.4 mm, hyaline, hoary towards apex; corolla hyaline; stipe of corolla $0.8-1 \mathrm{~mm}$ long; lobes 3 , subequal, obtuse and hoary towards apex, $0.3-0.4 \times$ 0.1-0.2 mm, eglandular. Stamens 6, exserted; filaments $0.2-0.3 \mathrm{~mm}$, white; anthers subglobose, $0.25 \times 0.2 \mathrm{~mm}$, yellow. Pistillate flowers: pedicels $0.1-0.2 \mathrm{~mm}$; sepals 3 , free, oblanceolate, 1.3-1.5 $\times 0.4-0.5 \mathrm{~mm}$, keeled along back, obtuse and hoary towards apex, hyaline. Petals 3 , almost equalling sepals, oblanceolate, obtuse and hoary towards apex, $1-1.2 \times 0.2-0.3 \mathrm{~mm}$, eglandular. Ovary subsessile, ovoid, trigonous, $0.3-0.4 \times 0.2-0.3 \mathrm{~mm}$; style $0.2-0.3 \mathrm{~mm}$; stigmas 3, 0.8-1 mm long. Seeds obovoid-ellipsoid, $0.3-0.4 \times 0.2-0.3 \mathrm{~mm}$, golden yellow; cells of seed coat transversely elongated, aligned in vertical rows; appendages absent.

Distribution. Eriocaulon meenachilense is known only from the type locality, the Illikkal Hills in the southern Western Ghats, India (Figure 3). 

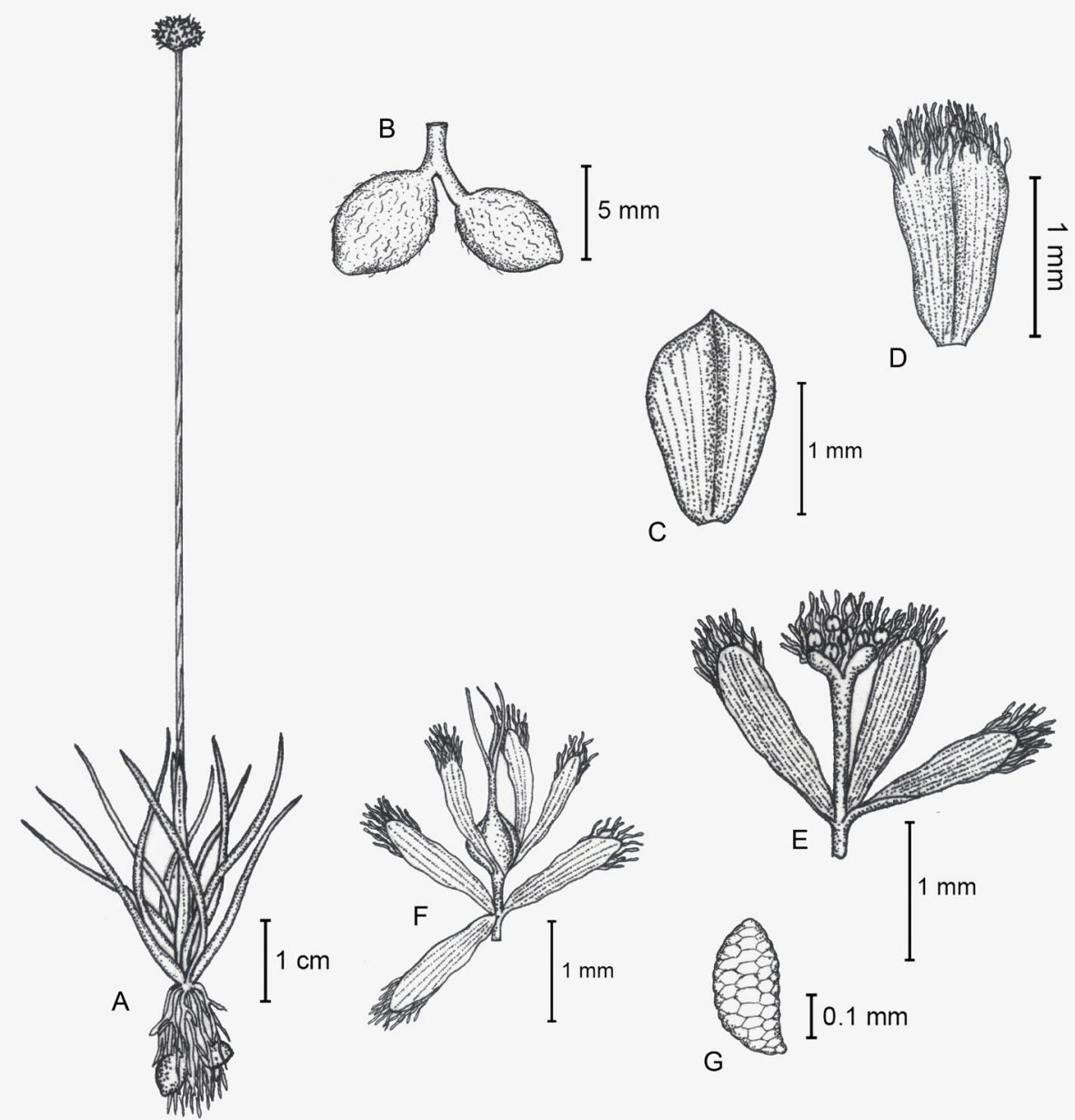

Figure 1. Eriocaulon meenachilense Anoop \& Robi, sp. nov. A, Habit; B, root tubers; C, involucral bract; D, floral bract; $\mathrm{E}$, male flower; $\mathrm{F}$, female flower; $\mathrm{G}$, seed. Drawn from the holotype, Anoop. P. B. \& A. J. Robi 15934 (MH), by P. B. Anoop. 

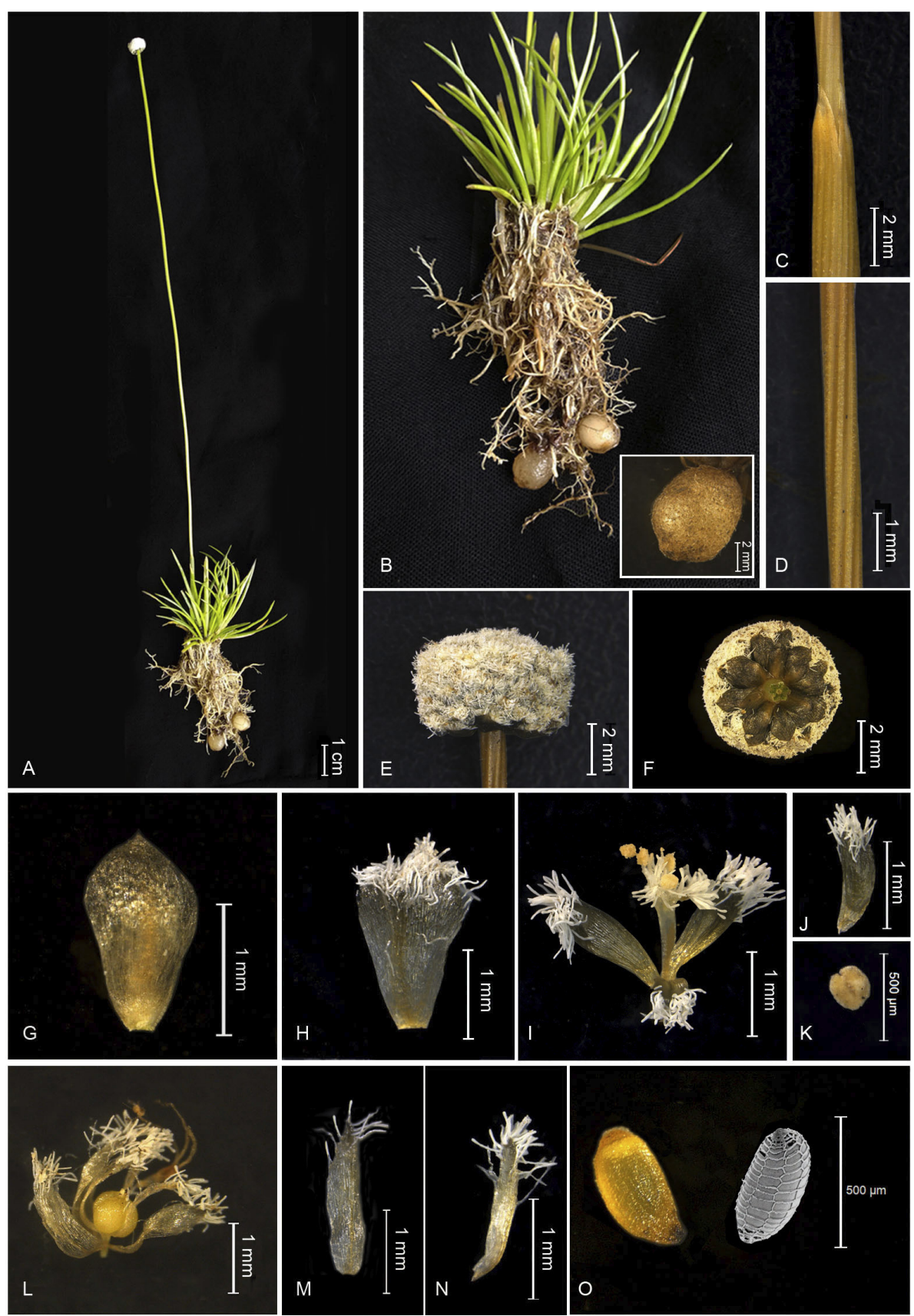

Figure 2. Eriocaulon meenachilense Anoop \& Robi, sp. nov. A, Habit; B, root tubers; C, sheath; D, twisted peduncle; $\mathrm{E}$, head (side view); $\mathrm{F}$, head (lower view); $\mathrm{G}$, involucral bract; $\mathrm{H}$, floral bract; I, male flower; $\mathrm{J}$, male sepal; $\mathrm{K}$, anther; $\mathrm{L}$, female flower; $\mathrm{M}$, female sepal; $\mathrm{N}$, female petal; $\mathrm{O}$, light and scanning electron microscopic images of seed. All from Anoop. P. B. \& A. J. Robi 15934. 


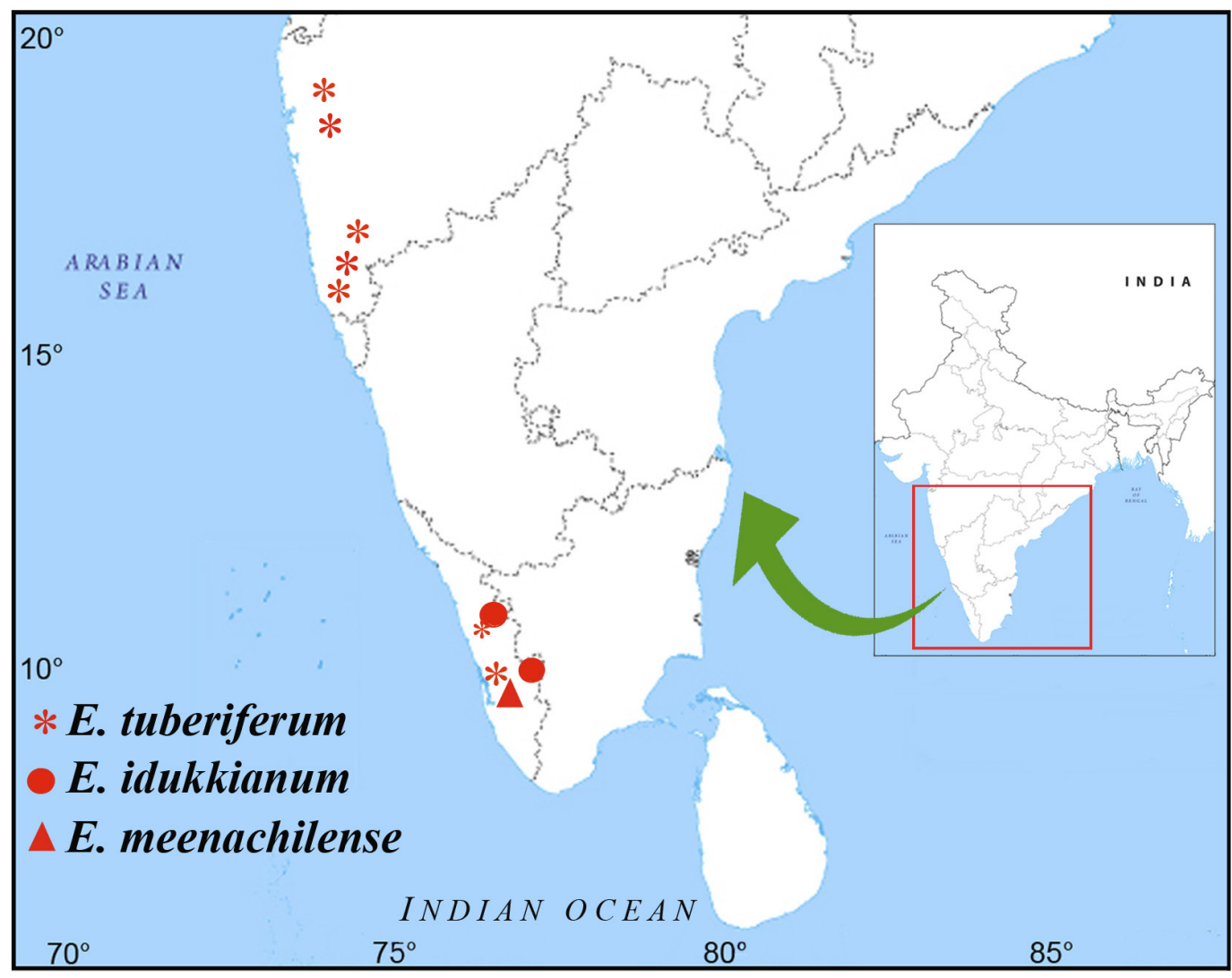

Figure 3. Map showing distribution of Eriocaulon idukkianum, E. meenachilense and E. tuberiferum in India.

Phenology. Flowering and fruiting from August to November.

Etymology. The specific epithet refers to the type locality, Meenachil Taluk in Kottayam District, Kerala, India.

Habitat and ecology. Wet rocky grasslands in association with Eriocaulon thwaitesii Körn., Exacum sessile L., Impatiens stolonifera Robi \& Manudev, Phyllocephalum scabridum (DC.) K.Kirkman, Smithia bigemina Dalzell, etc.

Conservation status. Eriocaulon meenachilense is endemic to the southern Western Ghats, India. The authors located 42 plants in four groups within an area of $200 \mathrm{~m}^{2}$. More extensive field surveys are required to better understand the true extent of occurrence and area of occupancy of this species. According to IUCN criteria, the species falls under the category Data Deficient (IUCN, 2012; IUCN Standards and Petitions Subcommittee, 2019).

Eriocaulon tuberiferum has so far been reported from the northern Western Ghats in 
Maharashtra State and southern Western Ghats in Kerala State (Sunil et al., 2018). The species is usually seen in the margins of puddles and open wet rocky slopes at 900-2100 m elevation. Eriocaulon idukkianum is confined to the southern Western Ghats in Kerala State and generally found at 2000-2300 m elevation in marshes near streams and rock crevices, in association with mosses. The major characters differentiating Eriocaulon meenachilense from the two other Indian tuberous species are listed in the Table.

Table. Comparison of the diagnostic morphological characters of Eriocaulon meenachilense sp. nov., E. idukkianum and E. tuberiferum

\begin{tabular}{llll}
\hline Character & E. meenachilense & E. idukkianum & E. tuberiferum \\
\hline $\begin{array}{l}\text { Rootstock } \\
\text { Root tubers }\end{array}$ & Absent & Present & Absent \\
Leaves & 2 or 3 , hairy & Single, glabrous & $2-15$, hairy \\
& Linear-subulate, up to $3.5 \mathrm{~cm}$ & Linear-oblong, up to $7 \mathrm{~cm}$ long, & Linear-lanceolate, up to \\
long, $0.2 \mathrm{~cm}$ broad & $0.4 \mathrm{~cm}$ broad & $5 \mathrm{~cm}$ long, $0.5 \mathrm{~cm}$ broad \\
Peduncle & Solitary, 6 -angled, up to $20 \mathrm{~cm}$ & $1-9,4$-angled, up to $26 \mathrm{~cm}$ & $1-3,4$-angled, up to $10 \mathrm{~cm}$ \\
& long & long & long \\
Sheath & Up to $3 \mathrm{~cm}$ long & Up to $6 \mathrm{~cm}$ long & Up to $6 \mathrm{~cm}$ long \\
Heads & About $6 \mathrm{~mm}$ across, white & About $10 \mathrm{~mm}$ across, white & About 9 mm across, black \\
& & & or grey \\
Receptacle & Glabrous & Pilose & Glabrous \\
Involucral bracts & Inflexed, up to $1.5 \mathrm{~mm}$ long & Reflexed, up to $3.5 \mathrm{~mm}$ long & Reflexed, $2.5 \mathrm{~mm}$ long \\
Male sepals & Free & Free & Spathaceously fused \\
& & & except at the extreme tip \\
Male and female petals & Eglandular & With black gland & With black gland \\
Anthers & Yellow & White & White \\
Seeds & Yellow, appendages absent & Brown, appendages absent & Purple, cells of seed coat \\
& & & transversely elongated
\end{tabular}

\section{Acknowledgements}

The authors are grateful to the Director, KSCSTE-Malabar Botanical Garden and Institute for Plant Sciences (MBGIPS), Kozhikode, Kerala, India, for all the facilities provided for this work. The constant encouragement and support of Dr N. S. Pradeep, Senior Scientist, MBGIPS, Kozhikode, is also gratefully acknowledged. The authors are also thankful to the Principal, Bishop Abraham Memorial College, Thuruthicad, Pathanamthitta, for the facilities and support.

\section{References}

Ansari R, Balakrishnan NP. 2009. The Family Eriocaulaceae in India, revised edition. Dehra Dun: Bishen Singh Mahendra Pal Singh.

Anto PV, Reshma A. 2017. Eriocaulon pradeepii, a new species of Eriocaulaceae from South India.

Taiwania. 62(4):371-374. https://doi.org/10.6165/tai.2017.62.371

Biju P, Subrahmanya Prasad K, Ajith Kumar P, Augustine J, Raveendran K, Ansari R. 2012. Eriocaulon 
cheemenianum (Eriocaulaceae), a new species from Kerala, India. International Journal of Plant, Animal and Environmental Sciences. 2(4):176-179. http://www.ijpaes.com/admin/php/ uploads/252_pdf.pdf

Biju P, Josekutty EJ, Augustine J. 2017. Eriocaulon albotetrandra, a remarkable new species of Eriocaulaceae from the ponds in the lateritic plateau of Western Ghats, India. Webbia. 73(1):1-4. https://doi.org/10.1080/00837792.2017.1404300

Bole PV, Almeida MR. 1986. Material for the flora of Mahabhaleshwar-7. Journal of the Bombay Natural History Society. 83(3):570-602.

Chandore AN, Borude DB, Natekar PD, Madhav NA, Yadav SR. 2019. Eriocaulon rayatianum, a new species of Eriocaulaceae from the Konkan region of Maharashtra, India. Phytotaxa. 416(1):73-78. https://doi.org/10.11646/phytotaxa.416.1.9

Darshetkar AM, Datar MN, Tamhankar S, Choudhary RK. 2017. Eriocaulon parvicephalum (Eriocaulaceae), a new species from Western Ghats, India. Phytotaxa. 303(3):233-242. https://doi. org/10.11646/phytotaxa.303.3.3

Darshetkar AM, Datar MN, Ramachandra Rao G, Tamhankar S, Prabhukumar KM, Choudhary RK. 2019. Eriocaulon karaavalense (Eriocaulaceae), a new species from India based on morphological and molecular evidence. Annales Botanici Fennici. 56(4-6):305-316. https://doi. org/10.5735/085.056.0417

Francis D, Mohan V, Venugopal DK, Nampy S. 2020. A new species of Eriocaulon (Eriocaulaceae) from the southern Western Ghats of Kerala, India. Edinburgh Journal of Botany. 77(2):281-290. https:// doi.org/10.1017/S0960428620000013

Giulietti AM, Andrade MJG, Scatena VL, Trovo M, Coan Al, Sano PT, Santos FAR, Borges RLB, van den Berg C. 2012. Phylogeny, morphology and their implications for the taxonomy of Eriocaulaceae. Rodriguesia. 63(1):1-19.

IUCN. 2012. IUCN Red List Categories and Criteria, version 3.1, 2nd edition. IUCN Species Survival Commission. Gland, Switzerland, and Cambridge: International Union for Conservation of Nature.

IUCN Standards and Petitions Subcommittee. 2019. Guidelines for Using the IUCN Red List Categories and Criteria, version 14. Prepared by the Standards and Petitions Subcommittee. http://www. iucnredlist.org/documents/RedListGuidelines.pdf [Accessed November 2019.]

Khanna KK, Kumar A. 2019. Three new species of Eriocaulon L. (Eriocaulaceae) from India. Biological Forum - An International Journal. 11(2):21-26.

Leach GJ. 2017. A revision of Australian Eriocaulon (Eriocaulaceae). Telopea. 20:205-259.

Manudev KM, Robi AJ, Nampy S. 2015. Eriocaulon biappendiculatum, a new species of Eriocaulaceae from the southern Western Ghats, India. Edinburgh Journal of Botany. 72(2):219-223. https://doi. org/10.1017/S0960428615000086

Manudev KM, Robi AJ, Nampy S. 2017. Eriocaulon idukkianum, a new tuberous species of Eriocaulaceae from southern Western Ghats, India. Phytotaxa. 324(3):288-292. https://doi. org/10.11646/phytotaxa.324.3.5

Myrthong S, Kumar Y, Rao RR. 1983. Eriocaulon echinulatum Mart. (Eriocaulaceae) - a new record for India. Journal of the Bombay Natural History Society. 80:667-668. 
Nampy S, Manudev KM, Pradeep AK. 2011. Two new species of Eriocaulon (Eriocaulaceae) from India. Edinburgh Journal of Botany. 68(2):257-263. https://doi.org/10.1017/S0960428611000138

Naveen Kumar VV, Sunil CN, Remya Krishnan CR, Sanilkumar MG, Baiju EC. 2017. A new species of Eriocaulon (Eriocaulaceae) from Southern Western Ghats, Kerala, India. Webbia. 72(2):155-159. https://doi.org/10.1080/00837792.2017.1369690

Paithane VA, Bhuktar AS, Kashetti RP, Patil SB. 2017. A new species of Eriocaulon (Eriocaulaceae) from lateritic plateaus of Sindhudurg, Maharashtra, India. International Journal of Advanced Research. 5(10):858-862. https://doi.org/10.21474/IJAR01/5596

Rashmi K, Krishnakumar G. 2014. Eriocaulon gopalakrishnanum sp. nov. (Eriocaulaceae) from the Western Ghats, India. Nordic Journal of Botany. 32(2):146-149. https://doi. org/10.1111/j.1756-1051.2012.00030.x

Shimpale VB, Yadav SR. 2010. Eriocaulon belgaumensis: a new species of Eriocaulaceae from the Western Ghats of India. Kew Bulletin. 65:337-339. https://doi.org/10.1007/s12225-010-9204-5

Shimpale VB, Bhagat RB, Deshmukh RB, Yadav SR. 2009. A new species of Eriocaulon (Eriocaulaceae) from Maharashtra, India. Rheedea. 19(1 and 2):47-49.

Sunil CN, Naveen Kumar VV. 2015. A new species of Eriocaulon (Eriocaulaceae) from Western Ghats, India. Webbia. 70(2):211-215. https://doi.org/10.1080/00837792.2015.1050175

Sunil CN, Ratheesh Narayanan MK, Nandakumar MK, Sujana KA, Joseph PJ, Anil Kumar N. 2013. Eriocaulon kannurense (Eriocaulaceae), a new species from Kerala, India. International Journal of Plant, Animal and Environmental Science. 3(2):116-120.

Sunil CN, Ratheesh Narayanan MK, Sivadasan M, Alfarhan AH, Abdul Jaleel V. 2014. Eriocaulon vandaanamense sp. nov. (Eriocaulaceae) from Kerala, India. Nordic Journal of Botany. 33(2):155158. https://doi.org/10.1111/njb.00658

Sunil CN, Ratheesh Narayanan MK, Naveen Kumar VV, Nandakumar MK, Balakrishnan V. 2017. Eriocaulon govindiana sp. nov. (Eriocaulaceae), from southern Western Ghats, Kerala, India. Taiwania. 62(4):387-391. https://doi.org/10.6165/tai.2017.62.387

Sunil CN, Prabhukumar KM, Naveen Kumar VV, Thomas VP, Jagadeesan R, Balachandran I. 2018. Eriocaulon tuberiferum (Eriocaulaceae) a new record for South India. Nelumbo. 60(1):18-22. https:// doi.org/10.20324/nelumbo/v60/2018/118166

Swapna MM, Rajesh KP, Manju CN, Prakashkumar R. 2012. Eriocaulon madayiparense (Eriocaulaceae) - a new species from the foot hills of the Western Ghats of India. PhytoKeys. 10:19-23. https://doi. org/10.3897/phytokeys.10.2297

Vivek CP, Swapna MM, Suresh KK. 2010. Eriocaulon wayanadense (Eriocaulaceae), a new species from Kerala, India. Rheedea. 20(1):25-27.

Yadav SR, Potdar GG, Kumar A, Otaghvari AM, Sonkar A. 2008. Eriocaulon epedunculatum, a new species of Eriocaulaceae from the Western Ghats, India. Kew Bulletin. 63:503-505. https://doi. org/10.1007/s12225-008-9041-y 